\title{
Initiatives Required by Stakeholders in Provision of School Plant in Primary Schools in Enugu Education Zone
}

\author{
Philomena Ngozi Agbo \\ Department of Educational Foundations, University of Nigeria, Nsukka, Nigeria \\ Email: agbongozi2015@yahoo.com
}

Received 20 August 2015; accepted 21 September 2015; published 24 September 2015

Copyright (C) 2015 by author and Scientific Research Publishing Inc.

This work is licensed under the Creative Commons Attribution International License (CC BY). http://creativecommons.org/licenses/by/4.0/

(c) (i) 0pen Access

\section{Abstract}

The study sought to identify initiatives required from stakeholder in the provision of school plant in primary schools in Enugu Education zone. Three research questions were developed and answered. Survey research design was adopted by the study. The population for the study was 5488 while the sample was 645 selected using proportionate random sampling technique. A 24 item structured questionnaire developed from literature reviewed was used to collect data for the study. Three experts validated the instrument. The internal consistency of the items was determined using Cronbach Alpha method and a coefficient of 0.82 was obtained. The researcher administered the instrument with the help of 3 assistants. The data collected were analyzed using mean to answer the research question while the hypothesis was tested using t-test statistics. The study found out that there were 24 initiatives ( 8 initiatives each by PTA members, community leaders and government respectively) required from stakeholders for provision of school plant in primary schools in Enugu Education Zone. It was therefore recommended that the identified initiatives should be implemented by the stakeholders to provide school plant in primary schools in Enugu Education zone.

\section{Keywords}

Environment, Stakeholders, Initiatives, Resources, Materials

\section{Introduction}

Teaching and learning in schools require the utilization of school plant for effective transfer of knowledge and skills. School plant according to National Teachers Institute, (NTI, 2000), refers to sites, buildings and physical 
equipment in an institution. The author further stated that school plant are all the resources such as the laboratory equipment, chalks, boards, machines, tools and so on. In the assertion of Ugwusa (2003), school plant is defined as a consciously designed and controlled environment for promoting teaching and learning activities within the school. The author further opined that school plant is also things put together to protect the physical well beings of individuals associated with the school. Okafor (2003) defined school plant as the site where school programmes and activities take place or the environment where school curriculum is implemented. In this study, school plant means all the material resources (like school site, buildings, laboratory equipment, fields and games equipment, boards and machines) which are made available for effective teaching and learning. School plant is of special significance to learners.

A good school plant with the necessary facilities play a major role in fostering the development of good sanitation and healthful habits among children and staff (Castaldi in Anike \& Tari, 2011). When teachers work in a school, well equipped and furnished with material resources, their levels of motivation and stability on the job increases. Udosen (2012), observed that presence of school plant enhances students' achievement interests, improves students attendance to classes thereby reducing drop-out rate. Akwam (2005), outlined the following school plant as important to teaching and learning, school laboratory, library, school building and furniture and instructional materials.

Research has proved that the pupil's level of achievement in science subjects is affected by the availability of laboratory in school. In the teaching of science subjects, practical work is complemented with the theoretical concepts. School library according to Udo (1985) provides learners the opportunities for developing interest in school subjects thereby acquiring desirable social values. Edem (1982) observed that boarding system facilities provide a meeting point where children from diverse cultural and ethnic backgrounds learn to live and work together, thereby helping to enhance national consciousness and solidarity. It also exposes the learners to more opportunities as they have such routines as preps, naps and library periods. Most of these materials are utilized as instructional materials. Instructional materials are grouped into Audio-Visual and visual materials. Nwoji (2002), listed audio-visual instructional materials to include: filmstrips, projectors, slide projector, opaque projectors, television, motion pictures, transparencies. The author further stated that values of audio visual of school plant include: making learning more permanent, with high degree of interest for learners, gaining a real-life experience, which stimulates self-activity on the part of the pupils, and developing a continuity of thought. When the school plant is not available within the school environment, they can be provided by the stakeholders.

Stakeholders according to Hazel \& Jeric (2012), are individuals or institutions that are interested in the development of schools. In the contribution of Alabi, Oduwaiye, \& Fasasi (2012), stakeholders in education sector refers to the community, parents and teachers of a school. Stakeholders that can help in provision of school plant are Parent Teachers Association (P.T.A), community and government. Parent Teachers Association according to Anambra State of Nigeria Regulation for PTA (1976) in Alu, Eya, Odo, Ede, \& Ugwu (1997), is a voluntary welfare association of parents/guardians and the teachers in a particular school. In the view of Ukeje (1992), Parent Teachers Association is a formal establishment in the school system which comprises of parent whose children are currently registered as students in the school, and their teachers. In this study, parent teachers association is a compulsory welfare meeting of parents/guardians and teachers in each school in Enugu Education Zone. The PTA performs certain roles for the school. According to Ogbonnaya (2000), PTA contributes funds for the erection of classroom blocks in schools, through donation of corrugated iron sheet, cement, trips of sand, nails and wood for the building, in addition to funding extra-curricular activity materials such as badminton kits, valley ball, basketball, lawn tennis; procuring furniture like desk, tables and chairs, chalk, office equipment and other instructional materials. Most often the PTA members provide such funds through compulsory levies to individual students. Apart from PTA members school plant can also made available to school by the community members.

Community according to Alu et al. (1997), is a group of people, in a certain territory that share a mode of life. In the assertion of Ogbonnaya (2000), community includes towns, villages, associations and age grades. In the opinion of Ngoka (2003), community is a group of people living in the same locality and having a common cultural and historical heritage as well as willingness to work together. In this study, community is a group of people in the same town, village or place living together where school is sited and are willing to provide school plant for effective teaching and learning with common interest. For effective teaching and learning to take place, the community must perform certain roles: like erecting building such as classrooms, libraries, offices or administrative blocks, toilet facilities and urinals and handing over to the government; providing desks, chairs and 
tables for effective running of the school (Ogbonnaya, 2002). The author further stated that community can donate land for building of schools and money for provision of equipment and relevant materials in the school; teachers quarters among others. School plant can also be made available to schools by the government.

Government in the contribution of Oyeneye, Onyenwenu, \& Olosunde (2006), is a body established by a state, and vested with the power and authority to make and maintain law, and order for the protection of lives and properties, as well as provide for the welfare of citizens. Government according to Oji \& Okafor (2000) is a machinery of state set up to facilitate the role of the state in society. Governments are machineries of a state set up to facilitate teaching and learning by providing school plant. The government therefore plays important role in the provision of school plant. According to Ogbonnaya (2000), government is responsible for the distribution of school equipment, furniture, registers, diaries, chalk, dusters and text books to schools, and also embarks on capital projects like building classroom and administrative blocks, provide teaching library aids, and stationery. For efficient, effective, and consistent provision of school plant the stakeholders need to be persuaded through certain initiatives.

Initiative according to Iannarino (2010) is the ability to take action pro-actively. It is the ability to perform what is expected before anyone reorganizes the need to perform such action in order to succeed. That is acting before being given directions and instructions. The author further explained that initiative urges an individual to take decision in order to achieve a positive outcome without being directed by another person. Audra (2015) explained initiative as a description of the direction that needs to be taken and how such could improve the outcome or an action taken to indicate future tasks. Initiative therefore means actions that stakeholders could take to ensure consistent availability of school plant to enhance the achievement of the objectives of primary school education. That is initiative is a new plan of action that could induce the PTA members, community members and government to provide school plant for effective teaching and learning in primary schools in Enugu Education zone.

Primary school is an institution for children aged 6 to 11 years (FRN 2014). Primary school prepares learners (Pupils) for present living, and in the foreseeable future. The preparation of learners is made possible through the use of adequate school plant like buildings. School plant like buildings therefore helps to protect teachers and pupils from sun, heat, rains, and cold. It also enhances the comfort and safety of teachers and pupils thereby increasing their performance.

Despite the government policies to promote education to enhance academic performance of the primary school pupils, it seems that little impact has been created in provision of school plant. This is because school plant is hardly available in the right quality and quantity. Even the available ones seem to be in deplorable condition. Inadequacy of major physical facilities needed in school/classrooms for effective and quality teaching and learning poses a serious concern to the general public in Enugu State (Ugwuanyi, 2005). Such physical facilities as school laboratory and library, building and furniture and instructional materials are not available and the available ones are not in good condition. Akwam (2005) observed that in some classrooms, pupils' desks and chairs, teachers' tables as well as chalk boards are inadequate. In such situations about six to eight pupils share a bench meant for only five pupils. The pupils may not be attentive to lessons because they are not comfortable. The author further indicated that in some other schools, pupils study under dilapidated buildings, some stay under the tree while others stay in a church open hall, village mini hall and the likes. Under these conditions there is likelihood that adequate teaching learning process is endangered, but these primary schools are established within the community. Also there are PTA members in each of these schools while the government is expected to facilitate teaching and learning. In most cases these stakeholders do not know what to do to enhance the availability of school plant. This is because it is believed that if they are aware, they could willingly provide the necessary facilities for teaching and learning. Therefore this study sought to identify initiatives required by the stakeholders in the provision of school plant in Enugu Education zone. Specifically, the study identified initiatives required by:

1) Stakeholders in the provision of school plant in primary schools in Enugu Education zone.

2) Community members in the provision of school plant in primary schools in Enugu Education zone

3) Government in the provision of school plant in primary schools in Enugu Education Zone.

\section{Methodology}

The study adopted a survey research design and was carried out in primary schools in Enugu Education zone. 
The population for the study was 5488 made up of 5000 PTA members 150 community leaders 308 administrators of primary schools (head teachers and assistant head teachers) and 30 ministry of Education (government) officials. The sample of the study was 645 respondents made up of 157 PTA members, 150 community leaders, 308 administrators and 30 government officials. The entire population of community leaders, administrators and government officials were used because of their manageable size, while proportionate random sampling techniques was used to select 30\% of PTA members from each school. The selection was made based on Ali (2006) that if a population is large, only a small size of it that the researcher can manage well ought to be sampled.

The instrument for data collection was a 24 questionnaire items developed from the literature reviewed, by the study. The items in the questionnaire were grouped into three (ABC). Each item from the questionnaire had a four response options of Highly Required (HR) Averagely Required (AR), Slightly Required (SR) and Not Required (NR) with values of 4, 3, 2, and 1 respectively. The questionnaire items were face-validated by three experts, all from the Educational Foundations department of University of Nigeria, Nsukka. The internal consistency of the items was determined using Cronbach alpha method and a coefficient of 0.82 was obtained. The researcher with the help of three assistants collected the data from the respondents. Prior to the assignment, the researcher instructed the assistants on how to collect data i.e. they were asked to request PTA members to react to the first set while community leaders and government officials were requested to react to second and third sets respectively. Administrators of schools i.e. head teachers and assistant head teachers reacted to all the three sets. The data was analyzed using mean to answer the research questions. In answering research questions, true limit of numbers was assigned to the response options highly required (HR-4) $=3.50-4.00$ : Averagely Required $($ AR-3 $)=2.50-3.49$ : Slightly Required $($ SR-2) $=1.50-2.49$ : Not Required $($ NR-1) $=0.000-1.49$.

In taking decision on the items required, any item with a mean value of 1.50 or above was required while any item with a mean value below 1.50 was not required.

\section{Result}

The result of the study was obtained from the research answered and presented in Tables 1-3.

\section{Research Question 1}

What are the initiatives required by stakeholders in the provision of school plant in primary schools in Enugu Education Zone?

The data for answering research question one were presented in Table 1.

Data presented in table 1 revealed that all the 8 items had their mean values ranged from 2.30 to 3.65 . This showed that the mean value of the items were above 1.50 indicating that the 8 items were initiatives required stakeholders in the provision of school plant in primary schools in Enugu Education Zone.

\section{Research Question 2}

What are the initiatives required by community members in provision of school plant in primary schools in

Table 1. Mean ratings of administrators and stakeholders on initiatives required by PTA members in provision of school plant in Primary Schools in Enugu Education Zone.

\begin{tabular}{|c|c|c|c|c|}
\hline $\mathbf{S} / \mathbf{N}$ & ITEM STATEMENT & $\bar{X}$ & SD & Decision \\
\hline & PTA members to: & & & \\
\hline 1 & Donate equipment individually or collectively to school & 3.65 & 0.68 & HR \\
\hline 2 & Equip libraries with text books and other stationeries for use by teachers, and pupils. & 3.21 & 0.72 & AR \\
\hline 3 & Provide security for pupils by fencing the play ground. & 3.15 & 0.77 & AR \\
\hline 4 & Persuade government to provide/support health care for the pupils. & 3.30 & 0.87 & SR \\
\hline 5 & Persuade government to supply toiletries to the school for teachers and pupils. & 2.30 & 0.87 & SR \\
\hline 6 & Provide pupils with appropriate dresses. & 3.60 & 0.6 & HR \\
\hline 7 & Provide teaching aids & 3.33 & 0.68 & AR \\
\hline 8 & Donate funds to schools & 3.40 & 0.68 & $\mathrm{AR}$ \\
\hline
\end{tabular}

$\mathrm{N}=645 . \quad \bar{X}=$ mean, $\mathrm{SD}=$ Standard deviation. 
Table 2. Mean ratings of administrators and community on initiatives required by community in Provision of School Plant in Primary schools in Enugu Education Zone. $\mathrm{N}=645$.

\begin{tabular}{|c|c|c|c|c|}
\hline $\mathrm{S} / \mathbf{N}$ & ITEM STATEMENT & $\bar{X}$ & SD & Decision \\
\hline \multicolumn{5}{|c|}{ Community members to: } \\
\hline 1 & Provide land to establish school and for Agricpracticals. & 3.60 & 0.68 & HR \\
\hline 2 & Provide houses for teachers who want to live within the community at how lost. & 3.20 & 0.71 & AR \\
\hline 3 & Provide adequate security for school environment. & 3.10 & 0.73 & AR \\
\hline 4 & Assist in the construction of access roads to the school. & 2.80 & 0.81 & AR \\
\hline 5 & Assist in providing recreational facilities for the pupils and the community. & 3.60 & 0.68 & HR \\
\hline 6 & Assist in provision of indoor furniture e.g. chairs and tables & 3.61 & 0.68 & HR \\
\hline 7 & Persuade the philanthropists to supply vehicles to school. & 3.70 & 0.61 & HR \\
\hline 8 & Provide a well equipped civic center for pupils. & 3.60 & 0.68 & HR \\
\hline
\end{tabular}

Table 3. Mean ratings of administrators and by government officials on initiative required by Government in Provision of School Plant in Primary Schools in Enugu Education Zone. $\mathrm{N}=645$.

\begin{tabular}{|c|c|c|c|c|}
\hline $\mathbf{S} / \mathbf{N}$ & Item Statement & $\bar{X}$ & SD & Decision \\
\hline & Government to: & & & \\
\hline 1 & Create awareness through the media about the importance of primary education in the state. & 3.70 & 0.61 & HR \\
\hline 2 & $\begin{array}{l}\text { Publicize through media, the need to obtain guidelines for establishing primary schools } \\
\text { by the community. }\end{array}$ & 3.60 & 0.68 & HR \\
\hline 3 & Supply stationeries for schools use. & 3.20 & 0.71 & AR \\
\hline 4 & Help in the training of personnel. & 3.60 & 0.68 & $\mathrm{HR}$ \\
\hline 5 & Donate computers and text books for teachers and pupils. & 3.10 & 0.73 & AR \\
\hline 6 & Approve visits and health talks on health issues by medical officers. & 2.80 & 0.84 & AR \\
\hline 7 & Organize workshops or retraining programmers for teachers. & 3.60 & 0.68 & HR \\
\hline 8 & Build administrative, classroom and toilet blocks for school. & 2.86 & 0.81 & AR \\
\hline
\end{tabular}

Enugu Education Zone?

The data for answering research question two were presented in Table 2.

Data presented in Table 2 revealed that all the 8 items had their mean values ranged from 2.80 to 3.70. These values showed that the means were above 1.50 indicating that the 8 items were initiatives, required from community in the provision of school in primary schools in Enugu Education Zone.

\section{Research Question 3}

What are the initiatives required by government in provision of school plant in primary schools in Enugu Education Zone?

The data for answering research question three were presented in Table 3.

Data presented in Table 3 revealed that all the 8 items had their mean values ranged from 2.80 to 3.70. This showed that the means were above 1.50 indicating that the 8 items were initiatives required from government in the provision of school plant in primary schools in Enugu Education zone.

\section{Discussion of the Findings}

The study found out that 8 initiatives were required from stakeholders, they include donation of zinc, sand, nails, wood, chairs desks, tables and others. The findings were in agreement with the findings of Okoro in Okenwa \& Igbo (2013), who found out that zinc, sand, nails wood, football, basketball valley ball kits, building of assembly, 
examination and classroom halls are the responsibilities of PTA to provide for schools. The findings of the study were also in conformity with Alu et al. (1997), that assembly halls, and classroom blocks are the responsibilities of stakeholders to provide for schools.

The study also revealed that 8 initiatives were required from community members, they include provision of desk, chairs, donation of land and others. The findings were in consonant with the view of Ogbonnaya (2000), who found out that pipe born water, toilet facilities and electricity are the responsibilities of community to provide for school.

The study found out that 8 initiatives were required from government, they include provision of diaries, registers, dusters, chalk, building classrooms and administrative blocks, the others are the responsibility of government to provide for schools. The findings were in agreement with Udosen (2012) who found out that chalk, register and others are the responsibilities of government to provide for schools. The findings of the study, were also in agreement with Federal Republic of Nigeria (2014), that provision of textbooks and libraries are the responsibilities of government to primary schools.

\section{Conclusion}

The Enugu Education zone is interested in ensuring that primary school pupils get quality education when there is school plant. Therefore, if the findings of this study are carefully considered for implementation, it may help achieve the intension of the government for these pupils in primary schools in the zone.

\section{References}

Akwam, E. U. (2005). Management of Secondary School Plant in Nsukka L.G.A. Unpublished MED, Nsukka: Thesis Department of Educational Foundations, University of Nigeria.

Alabi, A. T., Oduwale, R. O., \& Fasasi, Y. A. (2012). Learning Environmental in Nigerian Primary Schools: Challenges to Educational Administrators. A Journal of Education Research and Development, 7.

Alu, B. E., Eya, L. O., Odo, C. O., Ede, F. E., \& Ugwu, J. C. (1997). Fundamentals of Educational Administration. Enugu: Calvary Side Printing \& Publishing Co.

Anike, L. O., \& Tari, G. N. (2011). Provision and Management of School Facilities for the Implementation of UBE Programme. A Journal of Educational and Social Research, 1.

Audra, B. (2015). What Is a Business Initiative. http://smallbusiness.chron.com/business-initiative-23201.htm

Edem, D. A. (1982). Introduction to Educational Administration. Calabar: University Press.

Federal Republic of Nigeria (2014). National Policy on Education. Abuja: NERDC.

Hazel, B. A, \& Jeric, D. (2012). Implementing the Curriculum Roles of Stakeholders. Published in Education Technology.

Iannarino, A. (2010). Initiatives. http://thesaleblpg.com/blog/2010/01/30/inotiative-the-ability-to-take-action-proactively/

National Teacher's Institute (2000). School Administration and Management 111. NCE/DLS Course Book on Education, 4, 129-153.

Ngoka, G. N. (2003). Concept and Issues Advanced Education Administration Nsukka. Nsukka: University of Nigeria.

Nwoji, O. J. (2002). Production of Utilization of Teaching Materials. Enugu: Fulladu Publishing Company.

Ogbonnaya, N. O. (2000). Foundation of Education Finance (2nd ed.). Onitsha: Cape Publisher International Ltd.

Oji, O. R., \& Okafor, C. (2000). Political Parities, Pressure Groups \& Public Opinion in the Political Process.

Okafor, F. O. (2003). Evaluation of School Plant Adequacy, Usage and Maintenance in Secondary Schools in Idemili North Local Government Authority. Unpublished M.E.D. Thesis, Nsukka: Department of Educational Foundations, University of Nigeria.

Okenwa, G. N., \& Igbo, R. O. (2013). Extent of Community Participation in the Provision of School Plant in the Administration of Public Secondary Schools in Enugu State. Journal of Educational and Social Research, 3, 53-58.

Oyeneye, I., Onyenwenu, M., \& Olosunde, E. B. (2006). Round-Up Government for Senior Secondary Certificate, University matriculation and PCE Examinations (2nd ed.). Lagos: Longman Nigeria Plc.

Udo, U. M. (1985). The Need for School Libraries for the Successful Implementation of the 6-3-3-4. A Paper Presented at the National Seminar on the Implementation of 6-3-3-4. Lagos.

Udosen, N. P. (2012). Importance of School Plant to the Teaching-Learning Process.

Ugwuanyi, A. A. (2005). Evaluation of School Library Resources, Services and Usages: A Case Study of the Demonstration 
Secondary School Library. Curriculum and Media Technology Research: A Journal of CUMIMAC, Faculty of Education, $U N N, I, 335-541$.

Ugwusa, H. O. (2003). Management of School Plant in Post-Primary Institute in Enugu Education Zone. Unpublished M.E.D. Thesis, Nsukka: Department of Educational Foundations, University of Nigeria.

Ukeje, B. O. (Ed.) (1992). Education Administration. Enugu: Fourth Dimension Publishing Co. Ltd. 